STUDIA PRAWNO-EKONOMICZNE, T. CXV, 2020

PL ISSN 0081-6841; e-ISSN 2450-8179 s. 71-86

https://doi.org/10.26485/SPE/2020/115/4

\title{
Michał KRAKOWIAK*
}

iD https://orcid.org/0000-0002-6212-5517

\section{EGZEKUCJA Z RUCHOMOŚCI WEDŁUG WŁOSKIEGO KODEKSU POSTĘPOWANIA CYWILNEGO - ZAGADNIENIA WYBRANE}

\begin{abstract}
Abstrakt
Przedmiot badań: Regulacja polskiego Kodeksu postępowania cywilnego o egzekucji z ruchomości w sądowym postępowaniu egzekucyjnym, obowiązująca od 1.01.2019 r., jest kontrowersyjna w wielu aspektach. Skłoniło to do analizy rozwiązań ustawodawstw obcych. W niniejszym opracowaniu jako przedmiot badań przyjęto prawo włoskie. Wybór tego porządku prawnego podyktowany jest istnieniem oryginalnych instytucji w egzekucji z ruchomości, w szczególności $\mathrm{w}$ kwestiach zmienionych w prawie polskim od 1.01.2019 r.

Cel badawczy: Celem opracowania jest analiza warunków prawnych, w jakich przeprowadza się egzekucję z ruchomości we włoskim prawie egzekucyjnym. Przedmiotem zainteresowania Autora jest ustalenie, czy rozwiązania prawa polskiego wpisują się w model egzekucji z ruchomości obowiązujący w prawie włoskim. Autor postawił pytania dotyczące tego, w jaki sposób ustawodawca włoski uregulował zagadnienia miejsca przeprowadzania czynności zajęcia rzeczy, katalogu ruchomości bezwzględnie i względnie wyłączonych spod zajęcia, formy i czasu zajęcia, czynności zajęcia następczego oraz sprzedaż zajętych rzeczy.

Metoda badawcza: W opracowaniu posłużono się metodą dogmatyczną i prawnoporównawczą. Wyniki: W wyniku przeprowadzonej analizy włoskiego prawa egzekucyjnego i poglądów wyrażonych w doktrynie można dojść do wniosku, że w porównaniu z prawem obcym polskie przepisy o egzekucji z ruchomości są bardzo rygorystyczne i w praktyce zawężają zakres ich stosowania. Należy zwrócić uwagę na interesujące - z punktu widzenia dogmatyki prawa i praktyki egzekucyjnej - rozwiązania włoskiej egzekucji z ruchomości. Jak wynika z przeprowadzonych badań, ustawodawca wprowadził możliwość wydania w każdej sprawie na wniosek wierzyciela przez prezesa sądu lub wyznaczonego sędziego - zezwolenia komornikowi na zajęcie oznaczonych rzeczy, które nie znajdują się w miejscach należących do dłużnika, lecz podlegają sprzedaży egzekucyjnej. W prawie włoskim, inaczej niż w ustawodawstwie polskim, ustalono termin ważności czynności zajęcia, przyjmując, że traci ono moc po upływie czterdziestu pięciu dni, licząc od jego ukończenia w razie braku sprzedaży rzeczy lub zaliczenia ich wartości na poczet długu. Analiza prawnoporównawcza doprowadza także do wniosku, że polskie przepisy o sprzedaży zajętych w egzekucji ruchomości są bardzo sformalizowane. W prawie włoskim istnieją dwa zasadnicze
\end{abstract}

* Dr hab., prof. UŁ, Uniwersytet Łódzki, Wydział Prawa i Administracji, Katedra Postępowania Cywilnego I; e-mail: mkrakowiak@wpia.uni.lodz.pl 
sposoby spieniężenia rzeczy, tj. sprzedaż komisowa i licytacyjna, przy czym, co istotne, sprzedaż komisowa odbywa się zupełnie poza postępowaniem egzekucyjnym, bowiem zostaje przekazana podmiotowi trzeciemu do jej przeprowadzenia. Komisant sprzedaje rzeczy we własnym imieniu, na rachunek i zlecenie organu władzy publicznej.

Słowa kluczowe: dłużnik, wierzyciel, zajęcie mienia, prawo włoskie.

\section{Wstęp}

W nauce trafnie zauważono, że wraz ze wzrostem współpracy międzynarodowej w sprawach cywilnych i handlowych rośnie także potrzeba przeprowadzenia egzekucji na podstawie tytułów powstałych w innych państwach albo tytułów krajowych rozstrzygających stosunki między podmiotami z różnych państw. W praktyce egzekucyjnej powstaje zatem zagadnienie ustalania oraz stosowania obcego prawa materialnego i procesowego ${ }^{1}$. Wobec tego analiza rozwiązań prawnych w zakresie sądowej egzekucji z ruchomości według przepisów prawa włoskiego ma walor dogmatyczny i praktyczny.

Przepisy o egzekucji z ruchomości dłużnika zawarto w Księdze trzeciej - Postępowanie egzekucyjne (wł. processo di esecuzione), Tytule drugim - Egzekucja przymusowa (wł. espropriazione forzata), Części drugiej - Egzekucja przymusowa z majątku ruchomego przeciwko dłużnikowi (wł. espropriazione mobiliare presso il debitore) włoskiego Kodeksu postępowania cywilnego ${ }^{2}$. Zgodnie z art. 812 ust. 3 włoskiego Kodeksu cywilnego ${ }^{3}$ ruchomościami są wszystkie inne dobra niż wymienione wprost $\mathrm{w}$ tym przepisie, jako nieruchomości (ziemia, źródła wody, drzewa, budynki i inne konstrukcje, nawet jeśli połączone są z ziemią przejściowo, oraz generalnie wszystko to, co jest naturalnie lub sztucznie połączone $\mathrm{z}$ ziemią $)^{4}$; za ruchomości uważa się także energię naturalną, jeżeli przedstawia wartość ekonomiczną (art. 814 CC).

\footnotetext{
M. Kostwiński, Prawo obce w postępowaniu egzekucyjnym - zagadnienia wybrane, Przegląd Prawa Egzekucyjnego 2016/7, s. 31-32.

2 Codice di Procedura Civile, Regio Decreto 28 ottobre 1940, n. 1443, Gazzetta Ufficiale n. 253; dalej: CPC. Należy wyjaśnić, że przedmiotem egzekucji z majątku ruchomego jest prawo własności do rzeczy oraz wszelkie inne „słabsze” prawo, jeżeli ma charakter zbywalny, A.M. Soldi, Manuale dell'esecuzione forzata, CEDAM, Vicenza 2016, s. 799. W myśl ogólnej zasady z art. 2740 włoskiego Kodeksu cywilnego, dłużnik odpowiada za wykonanie zobowiązań całym swoim obecnym i przyszłym majątkiem.

3 Codice Civile, Regio Decreto 16 marzo 1942, n. 262, Gazzetta Ufficiale n. 79; dalej: CC.

4 Por. art. $46 \S 1$ k.c. polskiego Kodeksu cywilnego, ustawa z dnia 23 kwietnia 1964 r. Kodeks cywilny (tekst jedn. Dz.U. z 2019 r., poz. 1145 ze zm.); dalej: k.c.
} 
W ramach niniejszego opracowania zostaną przedstawione wybrane zagadnienia o włoskiej egzekucji z ruchomości, tj.: poszukiwanie ruchomości podlegających zajęciu $\mathrm{w}$ domu dłużnika $\mathrm{i}$ innych pomieszczeniach przez organ egzekucyjny (art. 513 CPC); katalog ruchomości bezwzględnie wyłączonych spod zajęcia (art. 514 CPC); ruchomości względnie niepodlegające zajęciu (art. 515 CPC); forma i czas zajęcia rzeczy (art. 518 i 519 CPC); kolejne zajęcie tej samej rzeczy (art. 524 CPC); sprzedaż rzeczy (art. 529 i nast. CPC).

Na wstępie należy ogólnie wskazać, że stronami włoskiej egzekucji z rzeczy ruchomych są - zasadniczo - wierzyciel i dłużnik. Zajęcie rzeczy następuje przez komornika na wniosek wierzyciela, którego roszczenie zostało stwierdzone tytułem egzekucyjnym; zajęcie musi być poprzedzone przesłaniem do dłużnika zawiadomienia o istnieniu tytułu egzekucyjnego i wezwania do zapłaty. Zajęcie może zostać skierowane wyłącznie przeciwko osobie zobowiązanej do spełnienia świadczenia pieniężnego w ramach tytułu egzekucyjnego.

Omówienie wymienionych rozwiązań włoskiej egzekucji z ruchomości pozwoli porównać je z nowymi regulacjami prawa polskiego, wprowadzonymi do Kodeksu postępowania cywilnego ${ }^{5}$ od dnia 1 stycznia 2019 r. ${ }^{6} \mathrm{~W}$ tym miejscu trzeba zatem zasygnalizować najistotniejsze zmiany dokonane w polskiej egzekucji z ruchomości. Otóż, znowelizowano art. 829 pkt 1 k.p.c. oraz dodano w tym przepisie nowy pkt $1^{1}$, których celem jest doprecyzowanie katalogu ruchomości niepodlegających zajęciu. Obecnie nie podlegają egzekucji przedmioty wprost wyszczególnione w wymienionym przepisie, przy czym, co istotne, ustawodawca wskazał, że wyłączenia spod egzekucji nie dotyczą tych przedmiotów, których wartość znacznie przekracza przeciętną wartość nowych przedmiotów danego rodzaju. W ramach nowelizacji dokonanej mocą u.k.s. nastąpiła istotna zmiana w zakresie właściwości miejscowej komornika prowadzącego egzekucję z ruchomości; zasadą jest, że egzekucja należy do komornika ogólnej właściwości dłużnika, czyli według miejsca zamieszkania, siedziby lub oddziału dłużnika (art. $844 \S 1$ k.p.c.). W świetle nowej regulacji właściwości miejscowej komornika przy egzekucji z ruchomości w praktyce powstaje wątpliwość, jak należy ustalić komornika miejscowo właściwego do przeprowadzenia egzekucji, jeżeli faktyczne miejsce położenia ruchomości jest inne niż miejsce zamieszkania, siedziby lub oddziału dłużnika ${ }^{7}$. Kolejną istotną zmianą, która prowadzi do

5 Ustawa z dnia 17 listopada 1964 r. Kodeks postępowania cywilnego (tekst jedn. Dz.U. z 2019 r., poz. 1460 ze zm.); dalej: k.p.c.

6 Mocą ustawy z dnia 22 marca 2018 r. o komornikach sądowych (Dz.U. z 2018 r., poz. 771); dalej: u.k.s.

7 Zob. szerzej M. Krakowiak, Kluczowe zagadnienia egzekucji z ruchomości w sadowym postępowaniu egzekucyjnym po 1.01.2019 r., Monitor Prawniczy 2019/18, s. 992-993. 
paraliżu egzekucji z ruchomości jest nowy paragraf 2 art. 845 k.p.c.; zgodnie $\mathrm{z}$ ujętym tam wyjątkiem nie podlegają zajęciu ruchomości, jeżeli z ujawnionych w sprawie okoliczności wynika, że nie stanowią one własności dłużnika. Trafnie przyjęto w nauce, że tym samym nastąpiło powiązanie przez ustawodawcę dopuszczalności zajęcia ruchomości z przysługiwaniem dłużnikowi jej własności. Ustawodawca uznał, że większej ochrony wymaga zapewnienie skutecznej ochrony osób trzecich, które nie są dłużnikami, a mogłyby zostać pozbawione własności rzeczy, niż zapewnienie skuteczności egzekucji. Natomiast, gdy przedstawiono niebudzący wątpliwości dowód na piśmie, że ruchomości nie stanowią własności dłużnika, komornik umarza postępowanie co do tych ruchomości. Nie dotyczy to sytuacji, gdy sam dłużnik dokonał zbycia ruchomości na rzecz osoby trzeciej (art. $845 \S 2^{2}$ k.p.c.) ${ }^{8}$. W dalszej części opracowania można przejść do porównania przywołanych rozwiązań prawa polskiego z prawem włoskim.

\section{Poszukiwanie ruchomości podlegających zajęciu}

Ustawodawca włoski w art. 513 CPC uregulował dopuszczalność poszukiwania rzeczy podlegających zajęciu przez organ egzekucyjny ${ }^{9}$. Zgodnie z przepisem, organ ten może wyszukiwać rzeczy nadających się do zajęcia w domu dłużnika i innych pomieszczeniach należących do niego. Może również przeszukać osobę dłużnika, przestrzegając zasad jego godności osobistej ${ }^{10}$. Ponadto, gdy konieczne jest otwarcie drzwi, schowków lub pomieszczeń, przezwyciężenie oporu dłużnika lub osoby trzeciej, lub usunięcie osób, które zakłócają wykonanie zajęcia, komornik podejmuje czynności stosowne do okoliczności, wzywając,

8 M. Krakowiak, Kluczowe zagadnienia..., s. 995-998; zob. także A. Kościółek, Zmiany w przepisach o zajęciu ruchomości w egzekucji sądowej, w: A. Marciniak (red. nauk.), Analiza i ocena ustawy o komornikach sadowych oraz ustawy o kosztach komorniczych, Currenda, Sopot 2018, s. 608-613; S. Cieślak, w: J. Jankowski (red.), Kodeks postępowania cywilnego. Tom II. Komentarz. Art. 730-1217, C.H. Beck, Warszawa 2019, Nb 2 do art. 845, s. 630-631.

9 Na temat ogólnej regulacji wyjawienia majątku dłużnika we włoskim postępowaniu egzekucyjnym zob. M. Krakowiak, Wyjawienie majątku dtużnika w postępowaniu egzekucyjnym w prawie hiszpańskim, włoskim i niemieckim, Studia Prawno-Ekonomiczne, 2016/XCVIII, s. 79-83; M. Muliński, Zasada nieobciążania ponad potrzebe strony biernej postęowania zabezpieczajacego i egzekucyjnego, Currenda, Sopot 2017, s. 264-265.

10 Przywołana regulacja odpowiada treści polskiemu art. 814 § 1 k.p.c. Zgodnie z przepisem, gdy cel egzekucji tego wymaga, komornik zarządzi otworzenie mieszkania oraz innych pomieszczeń i schowków dłużnika, jak również przeszuka jego rzeczy, mieszkanie i schowki. Gdyby to nie wystarczyło, komornik może ponadto przeszukać odzież, którą dłużnik ma na sobie. 
W razie potrzeby, pomoc policji. W każdym przypadku komornik może zająć, zgodnie z niniejszymi przepisami, rzeczy dłużnika znajdujące się w posiadaniu osoby trzeciej, za jej zgodą ${ }^{11}$.

W nauce włoskiej przyjęto pod pojęciem domu dłużnika w znaczeniu szerokim: miejsce, w którym dłużnik prowadzi swoje główne sprawy i interesy, jak i miejsce jego zwykłego pobytu, pod warunkiem, że realizuje tam swoje zasadnicze, codzienne zwyczaje i rozwija normalne relacje społeczne. Natomiast „inne pomieszczenia należące do dłużnika” to miejsca, które muszą zostać zindywidualizowane pod względem tego, czy dłużnik ma co do nich prawo własności albo chociażby wyłączne użytkowanie, niezależnie od charakteru związku dłużnika z tym miejscem. Wskazano, że z językowego punktu widzenia, prawidłowe jest posługiwanie się zwrotem „miejsce związane” $\mathrm{z}$ dłużnikiem, a nie ,przynależne" 12 .

Należy zwrócić także uwagę na rozwiązanie procesowe istotne dla praktyki egzekucyjnej. Otóż, prezes sądu lub wyznaczony przez niego sędzia, na wniosek wierzyciela, może zezwolić komornikowi, mocą zarządzenia, na zajęcie oznaczonych rzeczy, które nie znajdują się w miejscach należących do dłużnika, lecz podlegają sprzedaży (art. 513 ust. 3 CPC). Zatwierdzenie zajęcia rzeczy następuje bez uprzedniego wysłuchania dłużnika bądź osoby trzeciej ${ }^{13}$. Jako przykład takich rzeczy wskazuje się samochód pozostawiony w garażu ${ }^{14}$, rzeczy zdeponowane w skrytce bankowej ${ }^{15}$, dzieła sztuki (np.: obrazy) wystawione $\mathrm{W}$ galerii oddanej do dyspozycji tego artysty ${ }^{16}$. W nauce włoskiej podniesiono, że wskazana regulacja oparta jest na domniemaniu istnienia stosunku prawnego między dłużnikiem a osobą trzecią, na podstawie którego dłużnik ma dostęp do pomieszczeń osoby trzeciej, może doglądać złożone tam rzeczy, prezentować je innym, zabrać je. Jednocześnie, osoba trzecia nie jest posiadaczem tych rzeczy, a zachowuje $\mathrm{z}$ nimi pewien związek wynikający jedynie $\mathrm{z}$ umieszczenia ich w miejscach użytkowanych przez nią. Dłużnik korzysta z pomieszczeń osoby

Odpowiednikiem przywołanej regulacji w prawie polskim jest art. $845 \S 2$ zd. 3 k.p.c.

I. Schettini, Processo di esecuzione. Parte I, Roma 1962, s. 18.

13 M. Krakowiak, Czynność zajęcia $w$ egzekucji świadczeń pieniężnych $w$ świetle prawa włoskiego - zagadnienia wybrane, w: A. Barańska, S. Cieślak (red. nauk.), Ars in vita. Ars in iure. Księga jubileuszowa dedykowana Profesorowi Januszowi Jankowskiemu, C.H. Beck, Warszawa 2018, s. 436.

14 F.P. Luiso, Diritto processuale civile. Volume III - Il processo esecutivo, Giuffrè Editore, Milano 2011, s. 75.

15 C. Mancuso, La ricerca delle cose da pignorare, w: G. Arieta, F. De Santis, A. Didone (red.), Codice commentato delle esecuzioni civili, UTET Giuridica, Vicenza 2017, s. 780.

16 A.M. Soldi, Manuale dell'esecuzione forzata, s. 804. 
trzeciej tylko w celu dostępu do swoich rzeczy. Najczęściej na osobie trzeciej spoczywa ciężar dozoru nad rzeczami ${ }^{17}$. Należy zwrócić uwagę, że zajęcie rzeczy w trybie art. 513 ust. 3 CPC nie wymaga współpracy z osobą trzecią, pomimo że przeprowadzenie tej czynności egzekucyjnej wiąże się z wkroczeniem komornika do pomieszczeń (miejsc) o wyłącznym znaczeniu dla osoby trzeciej, $\mathrm{z}$ naruszeniem jej prawa do prywatności.

\section{Ruchomości bezwzględnie i względnie wyłączone spod zajęcia egzekucyjnego}

Włoski Kodeks postępowania cywilnego zawiera katalog rzeczy bezwzględnie wyłączonych spod zajęcia egzekucyjnego, przy czym trzeba pamiętać, że takie wyłączenia mogą znajdować się również w pozakodeksowych przepisach szczególnych. Wyłączenia egzekucyjne należy traktować jako wyczerpujące, ściśle interpretowane oraz niepodlegające wykładni rozszerzającej i stosowaniu w drodze analogii.

Bezwzględnie nie podlegają egzekucji rzeczy, którym przypisano charakter świętości ${ }^{18}$ (np.: wszelkie relikwie, ołtarze) oraz przedmioty służące do wykonywania praktyk religijnych ${ }^{19}$; obrączka, ubrania, pościel, meble (np.: stół z krzesłami, przy których podawane są posiłki dla dłużnika i jego rodziny oraz komoda na przybory domowe), przy czym, co interesujące, egzekucji podlegają łóżka o znacznej wartości ekonomicznej bądź o ustalonej wartości artystycznej lub antycznej. Wyłączenia te opierają się na względach humanitarnych, bowiem ustawodawca dał pierwszeństwo interesowi dłużnika przed prawem wierzyciela do uzyskania zaspokojenia należności, chroniąc potrzeby życiowe dłużnika i jego najbliższej rodziny. Nie można także zająć artykułów spożywczych i paliwa niezbędnych przez miesiąc do utrzymania dłużnika i mieszkających z nim członków jego rodziny. Ustawodawca włoski wyłączył spod zajęcia broń i inne przedmioty, które dłużnik przechowuje w celu wykonania służby publicznej (np.: toga sędziego, uzbrojenie żołnierza pozostającego w służbie) ${ }^{20}$. Kolejną kategorię rzeczy bezwzględnie wyłączonych stanowią wartościowe dekoracje,

Ibidem, s. 804.

18 O takim charakterze rzeczy rozstrzyga prawo kanoniczne.

19 Rzeczy takie nie są poświęcone ani pobłogosławione; są używane do sprawowania kultu na mocy formalnego aktu albo mocą faktów dokonanych (wł. per fatti concludenti), przy czym nie mogą one polegać wyłącznie na np.: umieszczeniu jakiejś figury na ołtarzu po to tylko, aby stała się przedmiotem służącym do sprawowania kultu i wyłączeniu spod egzekucji, A.M. Soldi, Manuale dell'esecuzione forzata, s. 812. 
listy, rejestry i wszelkie dokumenty rodzinne, a także rękopisy, chyba że stanowią część zbioru (zob. art. 514 CPC).

W wyniku nowelizacji art. 514 CPC dokonanej w 2015 r. $^{21}$, do katalogu rzeczy bezwzględnie niepodlegających zajęciu dodano także zwierzęta domowe ${ }^{22}$ i zwierzęta trzymane przy domu dłużnika lub w innych miejscach należących do niego (tj. zwierzęta podwórzowe), przy założeniu, że nie służą do celów produkcyjnych, spożywczych lub handlowych; ponadto zwierzęta wykorzystywane do celów terapeutycznych lub pomocy dłużnika, jego małżonka, partnera lub dzieci.

$\mathrm{W}$ art. $515 \mathrm{CPC}$ wymieniono rzeczy względnie wyłączone spod zajęcia, co nie jest związane $\mathrm{z}$ ich indywidualnymi właściwościami, ale z określoną sytuacją faktyczną. Zgodnie z przepisem, rzeczy służące do upraw i hodowli mogą być zajęte niezależnie od zajęcia samej nieruchomości, tylko w razie braku innych ruchomości, przy czym sąd egzekucyjny - na wniosek dłużnika i po wysłuchaniu wierzyciela - może wyłączyć spod zajęcia - mocą niezaskarżalnego postanowienia - te spośród opisanych wcześniej rzeczy, które są niezbędne do uprawy ziemi, albo może zezwolić na ich korzystanie po dokonanym zajęciu.

Włoski Kodeks postępowania cywilnego wprowadza także kategorię rzeczy podlegających zajęciu, ale tylko w pewnych okolicznościach czasu i miejsca. Otóż, owoce, które nie zostały jeszcze zebrane lub oddzielone od ziemi, nie mogą być zajęte oddzielnie od nieruchomości, do której przynależą, z wyjątkiem ostatnich sześciu tygodni przed zwykłym terminem ich zbioru ${ }^{23}$. Co interesujące, przepis art. 516 ust. 2 CPC wprost odnosi się do zajęcia egzekucyjnego jedwabników, co jest dopuszczalne tylko wtedy, gdy w większości znajdują się na gałęziach, tworząc kokon.

21 Legge 28 dicembre 2015, n. 221, Gazzetta Ufficiale 18 gennaio 2016, n. 13 (tzw. przepisy o zielonej gospodarce; „le norme sulla green economy”).

22 W nauce włoskiej wskazano, że pojęcie „Zwierzę domowe” (wł. animale da compagnia) jest zwrotem niejasnym i pozostawia miejsce na wątpliwości interpretacyjne. Nie jest bowiem jasne, czy należy je rozumieć w sensie szerokim i subiektywnym, czy też wyłącznie w sensie obiektywnym, posiłkując się do obowiązujących przepisów prawa w zakresie zwierząt, w szczególności do ustawy z 14 sierpnia 1991 r. o zwierzętach domowych (Gazzetta Ufficiale 30 agosto 1991, n. 203), przy czym ta ustawa stanowi wyłącznie o psach i kotach, natomiast milczy o innych zwierzętach domowych. Zaproponowano odwołanie się do definicji, zgodnie z którą „,zwierzę domowe i terapeutyczne to każde zwierzę trzymane lub przeznaczone do trzymania przez człowieka w celach towarzyskich bez celów produkcyjnych lub spożywczych, w tym takie, które wykonują czynności przydatne dla ludzi, jak pies dla osoby niepełnosprawnej, zwierzęta rehabilitacyjne i zatrudnione w reklamie. Natomiast dzikie zwierzęta nie są uważane za zwierzęta domowe, C. Mancuso, La ricerca ..., s. 791.

23 U. Rocco, Trattato di diritto processuale civile. IV. Parte Speciale. Processo esecutivo, Torino 1966, s. 183. 


\section{Forma i czas zajęcia rzeczy}

Rozważania w tej części opracowania należy poprzedzić wyjaśnieniem, że w nauce włoskiej wskazuje się, iż pojęcie „zajęcie” (wł. pignoramento) jest ogólnie akceptowane w dwóch znaczeniach, z których pierwsze, bardziej techniczne, odnosi się do pojęcia zajęcia jako czynności przymusowej (wł. atto in forza), na podstawie której konkretne dobra majątkowe dłużnika lub osoby trzeciej odpowiedzialnej za cudzy dług, zostają objęte (łac. manu iudicis) w celu prowadzenia egzekucji. Natomiast w drugim znaczeniu określa się zajęcie jako sytuację prawną (wł. situazione giuridica), rozumianą z kolei jako kompleks skutków procesowych i materialnoprawnych wynikających z aktu (czynności) zajęcia i utrzymujących się przez cały okres wywłaszczenia dłużnika z danego dobra majątkowego. W rzeczywistości pojęcie „zajęcie” odnosi się właściwie do czynności (aktu) organu egzekucyjnego, co do którego włoski Kodeks postępowania cywilnego i Kodeks cywilny regulują formę (łac. rectius) i skutki. Zajęcie jest czynnością typową i konieczną w toku egzekucji, wywołującą konsekwencje całkowicie ukierunkowane na wywłaszczenie dłużnika z jego mienia. Sama czynność zajęcia stanowi sankcję (wł. sanzione in atto), gdyż wraz $\mathrm{z}$ zajęciem mienia jego przedmiot zostaje wystawiony na konsekwencje, które wiążą się z tą czynnością ${ }^{24}$.

Komornik dokonuje zajęcia rzeczy, przy zachowaniu zasad z art. $492 \mathrm{CPC}^{25}$, sporządza protokół, w którym opisuje zajęte rzeczy i ich status, w tym za pomo-

24 M. Krakowiak, Wyjawienie majątku dtużnika..., s. 431; G. Costantino, Le espropriazioni forzate speciali. Lineamenti generali, Milano 1984, s. 20 i nast.

25 Artykuł 492 CPC jest przepisem ogólnym o formie zajęcia we włoskiej egzekucji sądowej. Zgodnie z tym przepisem zajęcie polega na wydaniu dłużnikowi przez komornika nakazu powstrzymania się od wszelkich czynności bezpośrednio zmierzających do usunięcia jego dóbr majątkowych i ich pożytków, które mogą być przeznaczone na spłatę należności wierzyciela, i jako takie wywłaszczone. Ponadto zajęcie musi również zawierać wezwanie dłużnika do złożenia oświadczenia o miejscu jego zamieszkania lub wyborze innego domicylu niż zajmowany, przy czym oświadczenie to składa się w sądzie egzekucyjnym, pouczając, że w przypadku nieobecności dłużnika w deklarowanym miejscu, korespondencja kierowana do niego zostanie złożona w sądzie egzekucyjnym ze skutkiem doręczenia. Ponadto zajęcie musi zawierać pouczenie dłużnika, że może żądać zastąpienia zajętych rzeczy lub praw złożoną sumą pieniędzy w wysokości odpowiadającej kwocie należności głównej, odsetek, kosztów i wydatków sądowych i kosztów egzekucyjnych wierzyciela egzekwującego (na wniosek, którego dokonano zajęcia) i wierzycieli przyłączających się. W przypadku gdy dla zaspokojenia wymienionych wcześniej wierzycieli zajęte mienie dłużnika wydaje się być niewystarczające albo jego spieniężenie może być długotrwałe, komornik wzywa dłużnika do wskazania innego mienia podlegającego zajęciu, miejsce, gdzie się znajduje, przypadające mu wierzytelności, 
cą dokumentacji fotograficznej oraz innych środków audiowizualnych (np.: nagranie filmowe) oznacza szacunkową wartość rzeczy - a na wniosek wierzyciela $-\mathrm{z}$ pomocą rzeczoznawcy. Jeżeli zajęcie obejmuje płody rolne, które jeszcze nie zostały zebrane lub oddzielone od ziemi, komornik opisuje ich charakter, jakość i lokalizację ${ }^{26}$. W nauce włoskiej wskazano, że opisany tryb postępowania komornika stanowi efektywną identyfikację majątku podlegającego zajęciu; odpowiada potrzebie jego ochrony przed usunięciem przez dłużnika, jak i zagwarantowaniu wierzycielowi, który nie uczestniczył w czynności zajęcia, prawa do zweryfikowania rzetelności oszacowania ${ }^{27}$. W sytuacji gdy komornik uzna za stosowne odroczenie wyceny zajętych rzeczy, sporządza pierwszy protokół z zajęcia, a następnie bezzwłocznie - a w każdym przypadku w terminie trzydziestu dni - dokonuje oszacowania na podstawie opinii rzeczoznawcy, który ma dostęp do miejsc położenia rzeczy. O kosztach sporządzenia opinii należnych rzeczoznawcy rozstrzyga sąd egzekucyjny - co interesujące - biorąc pod uwagę ostateczną kwotę uzyskaną ze sprzedaży (przejęcia i zaliczenia na poczet długu) wycenianych rzeczy, a w każdym innym przypadku, gdy nie doszło do zbycia - na podstawie podanej wartości szacunkowej. W protokole zajęcia komornik wskazuje zasady i przepisy dotyczące dozoru zajętych rzeczy.

Jeżeli dłużnik nie jest obecny przy zajęciu, komornik zobowiązuje osoby wymienione w art. 139 ust. 2 CPC, tj. członka rodziny lub osoby zarządzającej domem, biurem lub przedsiębiorstwem, pod warunkiem, że nie ma on mniej niż czternaście lat lub wyraźnej ułomności (niezdolności), do doręczenia dłużnikowi nakazu wzywającego do zapłaty długu; w przypadku nieobecności tych osób umieszcza awizo na drzwiach nieruchomości (lokalu), w której dokonał zajęcia.

Po zakończeniu czynności zajęcia, komornik przekazuje bezzwłocznie wierzycielowi protokół, tytuł egzekucyjny i nakaz wzywający dłużnika do zapłaty długu. Następnie wierzyciel musi złożyć we właściwym sądzie egzekucyjnym zawiadomienie o dokonanym spisie rzeczy wraz z uwierzytelnionymi kopiami wymienionych wcześniej dokumentów, w ciągu piętnastu dni od ich doręczenia; uwierzytelnienia dokumentów za ich zgodność z oryginałem dokonuje adwokat ustanowiony przez wierzyciela. W sądzie zakładane są akta

pod rygorem odpowiedzialności za składanie fałszywych lub niepełnych zeznań, zob. szerzej A. Bonsignori, Pignoramento, w: A. Azara, E. Eula (red.), Digesto Italiano. XIII, Torino 1966, s. 77-81; B. Capponi, Pignoramento, w: F.P. Casavola (red.), Enciclopedia Giuridica, Vol. XXIII, Roma 1990, s. 2-3.

26 Wymienione elementy są niezbędne do ustalenia, czy wystąpią warunki do przeprowadzenia egzekucji z płodów rolnych.

27 A.M. Soldi, Manuale dell'esecuzione forzata, s. 836. 
egzekucyjne. Do czasu upływu terminu, o którym stanowi się w art. 497 CPC, tj. zajęcie traci moc po upływie czterdziestu pięciu dni, licząc od jego ukończenia, w razie braku sprzedaży rzeczy lub zaliczenia ich na poczet długu, komornik przechowuje protokół zajęcia do dyspozycji dłużnika. Zajęcie rzeczy traci moc po upływie piętnastu dni od dnia złożenia w sądzie egzekucyjnym przez wierzyciela zawiadomienia o dokonanym spisie rzeczy wraz z uwierzytelnionymi kopiami wymienionych wcześniej dokumentów.

$\mathrm{Na}$ wniosek wierzyciela, złożony nie później niż w terminie do złożenia wniosku o sprzedaż rzeczy, sąd egzekucyjny - po powołaniu rzeczoznawcy, gdy uzna to za potrzebne - zarządza uzupełnienie zajęcia, jeżeli uzna, że szacunkowa wartość zajętych rzeczy jest niższa od wskazanej w protokole zajęcia przez komornika. W tym przypadku komornik bezzwłocznie ponawia czynność poszukiwania majątku dłużnika podlegającego zajęciu.

Stosownie do art. 519 CPC, zajęcia nie można wykonać w dni świąteczne oraz poza godzinami wskazanymi w art. $147 \mathrm{CPC}$, tj. przed godziną 7 rano i po godzinie 21 wieczorem, chyba że zezwoli na nie prezes sądu lub wyznaczony przez niego sędzia. Zajęcie rozpoczęte $\mathrm{w}$ dopuszczalnych godzinach można kontynuować, aż do jego ukończenia. Należy zwrócić uwagę, że powołany przepis nie określa wprost warunków koniecznych do uzyskania zgody prezesa lub wyznaczonego przez niego sędziego na przeprowadzenie zajęcia wbrew tej regulacji. W nauce przyjęto, że odstępstwo to jest dopuszczalne w przypadkach, w których opóźnienie w zajęciu może wywołać niebezpieczeństwo usunięcia mienia dłużnika i w każdym razie, gdy zachodzi potrzeba zabezpieczenia skuteczności zabezpieczenia ${ }^{28}$. Ponadto, CPC nie przewiduje żadnych sankcji procesowych $\mathrm{w}$ razie naruszenia wskazanego w art. 519 CPC dopuszczalnego czasu przeprowadzania zajęcia. Wobec tego wśród przedstawicieli doktryny włoskiej ukształtowały się dwa stanowiska. Zgodnie z pierwszym, stanowi ono zwykłe naruszenie art. 519 CPC, nieprowadzące do żadnych skutków procesowych; natomiast zgodnie z drugim, zajęcie egzekucyjne dokonane poza dopuszczalnymi terminami prowadzi do jego nieważności w rozumieniu art. $156 \mathrm{CPC}^{29}$. Warto zauważyć, że stosownie do art. 156 CPC zasadą jest, iż nieważność czynności procesowej nie zachodzi w przypadku niedopełnienia warunków formalnych, jeżeli wprost nie została wskazana w przepisie jako sankcja; przy czym nieważność może być stwier-

28 F. Bucolo, Il processo esecutivo ordinario, CEDAM, Padova 1994, s. 528.

29 G. Verde, Pignoramento mobiliare diretto e immobiliare, w: Enciclopedia Diritto, t. XXXIII, Milano 1983, s. 825; N. Castoro, P. Castoro, Il processo di esecuzione nel suo aspetto pratico, Milano 2017, s. 377 i nast.; F. Bucolo, Il processo..., s. 529. 
dzona, gdy czynność nie spełnia warunków formalnych koniecznych do osiągnięcia jej celu. Nieważność nigdy nie zachodzi, jeżeli czynność osiągnęła cel, do którego została podjęta.

\section{Kolejne zajęcie tej samej rzeczy}

We włoskim postępowaniu egzekucyjnym przyjęto zasadę, zgodnie z którą wielu wierzycieli może jednym aktem zajęcia objąć to samo mienie dłużnika. Raz zajęty majątek może następnie zostać zajęty także na wniosek kolejnego wierzyciela lub wielu wierzycieli. Przy czym każde zajęcie wywołuje indywidualne skutki (art. 493 CPC).

Komornik, podejmując kolejne zajęcie, tzw. terminowe (wł. pignoramento successivo tempestivo) - po stwierdzeniu, że wcześniejsze zajęcie zostało już ukończone - zaznacza to w protokole, w którym opisuje już zajęte rzeczy, a następnie przystępuje do zajęcia kolejnego mienia dłużnika albo zaznacza w protokole, że takiego nie ma. Protokół jest składany w sądzie egzekucyjnym i dołączany do akt założonych przy pierwszym zajęciu, jeżeli kolejne zajęcie zostanie dokonane przed terminem rozprawy, o której mowa w art. 525 ust. 1 CPC, tj. rozprawa wyznaczona w celu zatwierdzenia sprzedaży rzeczy lub jej przejęcia na poczet długu albo przed złożeniem odwołania od czynności sprzedaży rzeczy lub jej przejęcia na poczet długu. W takim przypadku kancelaria sądu egzekucyjnego zawiadamia wierzyciela, który jako pierwszy dokonał zajęcia, a dalsza egzekucja przebiega w ramach jednego postępowania egzekucyjnego.

Kolejne zajęcie, jeżeli zostanie dokonane po rozprawie lub po złożeniu odwołania, o których mowa wcześniej, także wywołuje skutki wobec rzeczy objętej pierwszym zajęciem, ale tylko w odniesieniu do ewentualnych dalszych zysków wynikających z zajęcia (tzw. kolejne zajęcie spóźnione, wł. pignoramento successivo tardivo). Jeżeli zajęcie dotyczy innych rzeczy, dla nich prowadzona jest odrębna egzekucja.

Przy kolejnym zajęciu nie ma obowiązku kierowania do dłużnika nowego nakazu i wezwań, o których mowa w art. 492 CPC, ale w celu oszacowania zajętego mienia i dozoru kolejny komornik musi powtórzyć te czynności, które dokonano przy pierwszym zajęciu ${ }^{30}$. W nauce włoskiej wskazano, że powtórne zajęcie danej rzeczy może nastąpić także na wniosek wierzyciela, którego dotyczy pierwsze zajęcie. Taka sytuacja wystąpi, gdy wierzyciel ma

30 C. Mancuso, La ricerca ..., s. 836. 
uzasadnioną wątpliwość, że pierwsze zajęcie dotknięte jest wadą prawną, która mogłaby doprowadzić do stwierdzenia jego nieważności; chcąc uniknąć takich wątpliwości skuteczności pierwszego zajęcia, wierzyciel kieruje kolejne zajęcie tej samej rzeczy ${ }^{31}$.

\section{Sprzedaż zajętej rzeczy}

We włoskiej egzekucji istnieją dwa zasadnicze sposoby spieniężenia zajętego mienia ruchomego, tj. sprzedaż komisowa i licytacyjna.

Sprzedaż komisowa uregulowana jest szczegółowo w art. 532 i 533 CPC. Polega ona na powierzeniu sprzedaży ruchomości, uprzednio oszacowanej przez rzeczoznawcę, za cenę minimalną wyznaczoną przez sąd egzekucyjny - podmiotowi, który sprzedaje ją w drodze negocjacji prywatnych, na podstawie umowy, którą zawiera $\mathrm{z}$ nabywcą. Zlecenie sprzedaży rzeczy przyznawane jest z reguły sądowej instytucji zajmującej się sprzedażą; może być przyznane innemu podmiotowi, ale tylko wtedy, gdy dotyczy szczególnych ruchomości, wymagających współpracy ze sprzedawcą specjalizującym się w danej branży. W opisanym przypadku spieniężenie majątku ruchomego zajętego u dłużnika ma charakter, cechy i skutki zwykłej, negocjowanej umowy sprzedaży ruchomości. Co interesujące, sprzedaż odbywa się poza postępowaniem egzekucyjnym, bowiem zostaje przekazana podmiotowi trzeciemu. Komisant sprzedaje rzeczy we własnym imieniu, ale na rachunek i zlecenie organu władzy publicznej zostaje zawarta umowa (kontrakt) i tym samym prawo prywatne zostaje wykorzystane do celów publicznych, a w konsekwencji znajdują zastosowanie przepisy ${ }^{32}$ art. 1153 CC (skutki prawne nabycia posiadania ruchomości), 2919 CC (skutek przenoszący prawa na nabywcę przy sprzedaży przymusowej), 2920 CC (prawa osób trzecich do sprzedanej rzeczy ruchomej) ${ }^{33}, 2921$ CC (rękojmia za wady rzeczy).

W postępowaniu egzekucyjnym uznaje się w pełni wiążące skutki umowy zawartej pomiędzy pośrednikiem (komisantem) a nabywcą. Komisant ma pra-

31 B. Capponi, Lineamenti del processo esecutivo, Bologna 2008, s. 170.

32 I. Schettini, Processo di esecuzione, s. 39.

33 Warto wskazać, że zgodnie z tym przepisem, gdy przedmiotem sprzedaży jest ruchomość, ten, któremu przysługiwało wobec niej prawo własności albo inne prawo realne, ale nie zgłosił swoich praw do sumy uzyskanej ze sprzedaży egzekucyjnej, nie mogą ich dochodzić przeciwko nabywcy będącemu w dobrej wierze ani wierzycielowi, który uzyskał zaspokojenie $\mathrm{z}$ tej sumy. Odpowiedzialność odszkodowawczą ponosi tylko wierzyciel będący w złej wierze. 
wo do wynagrodzenia ustalonego przez sąd egzekucyjny, jeśli udokumentuje przeprowadzenie sprzedaży i wpłaci uzyskaną z niej kwotę ${ }^{34}$. Komisant musi zapewnić zainteresowanym możliwość obejrzenia rzeczy, w tym również za pomocą środków elektronicznych, na co najmniej trzy dni przed wyznaczonym terminem próby sprzedaży; nie może wydać rzeczy nabywcy przed uiszczeniem przez niego pełnej ceny kupna.

Sprzedaż licytacyjna uregulowana jest w art. 534-538 CPC. Ten rodzaj sprzedaży może zostać powierzony urzędnikowi sądu, komornikowi lub instytucji do tego upoważnionej. Zazwyczaj jest powierzana sądowej instytucji prowadzonej w formie spółki, której celem jest m.in. sprzedaż przymusowa majątku ruchomego. Sąd egzekucyjny ustala cenę minimalną sprzedaży, termin licytacji (dzień, godzinę i miejsce); ponadto, co istotne, w dniach poprzedzających licytację upoważniona osoba odbiera ruchomości spod dozoru, gdyż muszą być na sprzedaży licytacyjnej, tak aby każdy uczestnik licytacji widział rzecz wystawioną na sprzedaż. Sąd egzekucyjny zarządza publiczne ogłoszenie o licytacji ruchomości w trybie art. 490 ust. 1 CPC, co oznacza publikację na portalu internetowym Ministerstwa Sprawiedliwości, w zakładce: publiczny portal sprzedaży, a ponadto może zlecić dokonanie ogłoszenia nadzwyczajnego na podstawie art. 490 ust. 3 CPC, co z kolei oznacza umieszczenie obwieszczenia o licytacji co najmniej czterdzieści pięć dni przed upływem terminu składania ofert - jeden raz lub więcej - w lokalnych gazetach o znacznym zasięgu lub w gazetach krajowych albo poprzez publikację za pomocą form reklamy komercyjnej. Licytację wygrywa osoba, która zaoferowała najwyższą cenę. Nabywca płaci cenę i odbiera rzecz, zaś podmiot organizujący licytację wpłaca uzyskaną kwotę, zachowując prawo do wynagrodzenia - tak jak przy sprzedaży komisowej ${ }^{35}$. W przypadku sprzedaży majątku ruchomego w drodze licytacji przeniesienie własności na nabywcę następuje w momencie zapłaty ceny; nie ma zatem zastosowania zasada konsensualności zobowiązań wyrażona w art. 1376 CC.

W razie bezskutecznej pierwszej licytacji podmiot odpowiedzialny za jej przeprowadzenie wyznacza kolejny termin, wystawiając rzecz po cenie sprzedaży niższej o $1 / 5$ od ceny poprzedniej (art. $538 \mathrm{CPC}$ ). Interesujące rozwiązanie prawne wprowadzono w art. 539 CPC, wyłączając bezwzględnie możliwość sprzedaży rzeczy ze złota i srebra po cenie niższej niż cena oszacowania. W przypadku gdy nie zostaną sprzedane w opisanym modelu, ich wartość zaliczana jest na poczet długu wierzycieli.

F.P. Luiso, Diritto processuale civile..., s. 142.

35 Ibidem, s. 143. 
Ustawodawca włoski wprowadził także szczególną formę dla sprzedaży ruchomości rejestrowanych, tj. w szczególności: pojazdów mechanicznych, wodnych, lotniczych. Sąd egzekucyjny może zlecić przeprowadzenie sprzedaży rzeczy w drodze licytacji bądź nie sądowemu instytutowi sprzedaży, a jeżeli taki nie jest zorganizowany, to innemu profesjonaliście: notariuszowi, adwokatowi, księgowemu wpisanych na odpowiednią listę prowadzoną w sądzie. W tym przypadku sprzedaż odbywa się według zasad sprzedaży nieruchomości z art. 591 bis CPC.

\section{Zakończenie}

Przedstawiona w niniejszym opracowaniu analiza wybranych, najistotniejszych instytucji prawa włoskiego $\mathrm{w}$ zakresie egzekucji z ruchomości upoważnia do wniosku, że rozwiązania te są mniej kazuistyczne i bardziej elastyczne w porównaniu z prawem polskim; w konsekwencji wpływają na skuteczność egzekucji i zaspokojenie należności wierzycieli.

Ustawodawca włoski w celu ułatwienia egzekucji dopuścił na wniosek wierzyciela możliwość zezwolenia komornikowi przez prezesa sądu lub wyznaczonego przez niego sędziego na zajęcie oznaczonych rzeczy, które nie znajdują się w miejscach należących do dłużnika, lecz podlegają sprzedaży egzekucyjnej.

Z kolei rozwiązaniem prawnym wpływającym ewidentnie na zabezpieczenie praw dłużnika we włoskiej egzekucji z ruchomości jest wprowadzenie terminu ważności czynności zajęcia i sankcji utraty jego mocy po upływie czterdziestu pięciu dni, licząc od jego ukończenia, w razie braku sprzedaży rzeczy lub zaliczenia ich wartości na poczet długu.

W porównaniu do prawa polskiego zwraca również uwagę nierozbudowana włoska regulacja o sprzedaży zajętego majątku ruchomego. Wprowadzono bowiem dwa zasadnicze sposoby spieniężenia rzeczy, tj. sprzedaż komisową i licytacyjną, przy czym - co jest szczególnym rozwiązaniem - sprzedaż komisowa odbywa się zupełnie poza postępowaniem egzekucyjnym, bowiem została przekazana podmiotowi trzeciemu. Komisant sprzedaje rzeczy we własnym imieniu, na rachunek i zlecenie organu władzy publicznej. 


\section{Bibliografia}

\section{Akty prawne}

Codice Civile, Regio Decreto 16 marzo 1942, n. 262, Gazzetta Ufficiale n. 79.

Codice di Procedura Civile, Regio Decreto 28 ottobre 1940, n. 1443, Gazzetta Ufficiale n. 253.

Legge 28 dicembre 2015, n. 221, Gazzetta Ufficiale 18 gennaio 2016, n. 13.

Ustawa z dnia 23 kwietnia 1964 r. Kodeks cywilny (tekst jedn. Dz.U. z 2019 r., poz. 1145 ze zm.).

Ustawa z dnia 17 listopada 1964 r. Kodeks postępowania cywilnego (tekst jedn. Dz.U. z 2019 r., poz. $1460 \mathrm{ze} \mathrm{zm}$.).

Ustawa z dnia 22 marca 2018 r. o komornikach sądowych (Dz.U. z 2018 r., poz. 771).

\section{Opracowania}

Bonsignori A., Pignoramento, w: A. Azara, E. Eula (red.), Digesto Italiano. XIII, Torino 1966.

Bucolo F., Il processo esecutivo ordinario, CEDAM, Padova 1994.

Capponi B., Lineamenti del processo esecutivo, Bologna 2008.

Capponi B., Pignoramento, w: F.P. Casavola (red.), Enciclopedia Giuridica. Vol. XXIII, Roma 1990, s. 1-1116.

Castoro N., Castoro P., Il processo di esecuzione nel suo aspetto pratico, Milano 2017.

Cieślak S., w: J. Jankowski (red.), Kodeks postępowania cywilnego. Tom II. Komentarz. Art. 730-1217, C.H. Beck, Warszawa 2019, s. 1-1945.

Costantino G., Le espropriazioni forzate speciali. Lineamenti generali, Milano 1984.

Kostwiński M., Prawo obce w postępowaniu egzekucyjnym - zagadnienia wybrane, Przegląd Prawa Egzekucyjnego 2016/7, s. 31-57.

Kościólek A., Zmiany w przepisach o zajęciu ruchomości w egzekucji sądowej, w: A. Marciniak (red. nauk.), Analiza i ocena ustawy o komornikach sadowych oraz ustawy o kosztach komorniczych, Currenda, Sopot 2018, s. 607-626.

Krakowiak M., Czynność zajęcia w egzekucji świadczeń pieniężnych w świetle prawa włoskiego-zagadnienia wybrane, w: A. Barańska, S. Cieślak (red. nauk.), Ars in vita. Ars in iure. Księga jubileuszowa dedykowana Profesorowi Januszowi Jankowskiemu, C.H. Beck, Warszawa 2018, s. 427-437.

Krakowiak M., Kluczowe zagadnienia egzekucji z ruchomości w sądowym postępowaniu egzekucyjnym po 1.01.2019 r., Monitor Prawniczy 2019/18, s. 992-1000.

Krakowiak M., Wyjawienie majątku dlużnika w postępowaniu egzekucyjnym w prawie hiszpańskim, wtoskim i niemieckim, Studia Prawno-Ekonomiczne 2016/XCVIII, s. 71-88.

Luiso F.P., Diritto processuale civile. Volume III - Il processo esecutivo, Giuffrè Editore, Milano 2011.

Mancuso C., La ricerca delle cose da pignorare, w: F. De Santis, A. Didone (red.), Codice commentato delle esecuzioni civili, G. Arieta, UTET Giuridica, Vicenza 2017, s. 772-791, s. $835-840$.

Muliński M., Zasada nieobciążania ponad potrzebę strony biernej postępowania zabezpieczajacego i egzekucyjnego, Currenda, Sopot 2017.

Rocco U., Trattato di diritto processuale civile. IV. Parte Speciale. Processo esecutivo, Torino 1966

Schettini I., Processo di esecuzione. Parte I, Roma 1962.

Soldi A.M., Manuale dell'esecuzione forzata, CEDAM, Vicenza 2016.

Verde G., Pignoramento mobiliare diretto e immobiliare, w: Enciclopedia Diritto, t. XXXIII, Milano 1983, s. 1-1030. 


\title{
Michał KRAKOWIAK
}

\section{EXECUTION OF MOVABLES ACCORDING TO THE ITALIAN CODE OF CIVIL PROCEDURE - SELECTED ISSUES}

\begin{abstract}
Background: The regulation of the Polish Code of Civil Procedure on the enforcement of movable property in enforcement proceedings, in force since 1.01.2019, is controversial in several aspects. This has inspired the comparative analysis of foreign language solutions.

In this study, Italian law was adopted as the subject of the study. The choice of this legal order was dictated by the existence of original institutions in the enforcement of movable property, in particular matters that were amended in Polish law from 1.01.2019.

Research purpose: The purpose of the study is to analyze the legal conditions in which the execution of movable property in Italian enforcement law is carried out. The subject of the author's interest is to determine whether the solutions of Polish law fit into the model of execution on movable property in Italian law. The author inquired whether the Italian legislator regulated the issues of: the location of seizing activities, the catalog of movable property absolutely and relatively excluded from the seizure, the form and time of seizure of movables, and the sale of seized items. Methods: Dogmatic and comparative law methods were used in the study.

Conclusions: As a result of analysing Italian enforcement law and the views expressed in the doctrine, it can be concluded that, in comparison with Italian law, Polish provisions on enforcement of movables are very strict and in practice they narrow the scope of their use. Attention should be paid to interesting - from the legal-dogmatical point of view and the enforcement practice - solutions of Italian enforcement of movable property. According to the research, the legislature introduced the possibility of, upon request by the creditor, the president of the court or a designated judge, permitting the bailiff to take custody of things that are marked as not belonging to the debtor but are subject to sale. In Italian law, unlike in Polish legislation, the period of validity for seizing movables was fixed, assuming that it loses its force after forty-five days, counting from its completion in the event of failure to sell things or counting their value towards debt.

A comparative legal analysis also leads to the conclusion that Polish provisions on the sale of movable property seized in the execution on property are very formalized. In Italian law, there are two main ways of monetizing things, i.e. commission and auction sales, and, importantly, commission sales take place completely outside of enforcement proceedings, as they are transferred to a third party for carrying them out. The commissioner sells things on his own behalf, for the account and commissioned by a public authority.
\end{abstract}

Keywords: debtor, creditor, seizure of movables, the Italian law. 